Vol. 9(2), pp. 86-94, February, 2015

DOI: 10.5897/AJ EST2014.1695

Artic le Number. 625B0B849819

ISSN 1996-0786

Copyright (c) 2015

Author(s) reta in the copyright of this a rticle

African Journal of Environmental Science and

http://www.academic joumals.org/AJ EST

Technology

Perspective

\title{
Is climate change human induced?
}

\author{
H. N. Misra and Ashutosh Mishra* \\ Geography Department, University of Allahabad, India. \\ Received 7 March, 2014; Accepted 22 December, 2014
}

\begin{abstract}
Climate is the most vital element of our planet and its liveability is key concern for every habitat. From Silent Spring till present, debate is on whether humankind has impact on nature. Since its establishment in 1988, the Intergovernmental Panel on Climate Change (IPCC) has been playing pivotal role in raising public concerns on human-induced climate change through its various assessment reports. These reports follow exhaustive review process, and are widely accepted. In 2007, IPCC's $4^{\text {th }}$ assessment report- 'Climate Change 2007 - Impacts, Adaptation and Vulnerability' came into question on Himalayan glacier melt. The climate gate in 2009 further strengthened the confusion on credibility of IPCC's projections. The present study analyses district level temperature and rainfall patterns of Uttarakhand- a Himalayan state, and examines the validity of IPCC's projection. Uttarakhand is a tourism oriented economy. The state is best known for its religious places and natural sites. Rapid urbanisation in mountainous regions is disturbing regional eco-balance, but increasing vehicular pollution in climatesensitive areas seems to have greater impact on temperature and precipitation patterns. Result shows a noticeable shift in the variability of temperature and rainfall, and a significant warming especially in mountainous districts. However, human activities do not correlate very well with these changes.
\end{abstract}

Key words: Climate-sensitive sectors, monsoon, climatic variability, polar caps, vehicular pollution.

\section{INTRODUCTION}

India is considered highly vulnerable to climate change, not only because of high physical exposure to climaterelated disaster, but also because of the dependency of its economy and majority of population on climatesensitive sectors (for example, agriculture, forests, tourism, animal husbandry and fisheries). More than 40 million hectares of India land (12\%) is prone to floods and river erosion; of the $7,516 \mathrm{~km}$ long coastline, close to $5,700 \mathrm{~km}$ is prone to cyclones and tsunamis; $68 \%$ of the cultivable area is vulnerable to drought and hilly areas are at risk of landslides and avalanches (NDMA, 2007). The country has a unique climate system dominated by the monsoon, and the major physiographic features that drive this monsoon are its location in the globe, the Himalayas, the
Central Plateau, the Western and Eastern Ghats and the oceans surrounding the region.

The Himalayas influence the climate of the Indian subcontinent by sheltering it from the cold air mass of Central Asia. The range also exerts a major influence on monsoon and rainfall patterns. They prevent frigid and dry arctic winds from blowing south into the subcontinent keeping South Asia much warmer when compared with regions located between corresponding latitudes throughout the globe.

Himalayan glaciers cover about three million hectares or $17 \%$ of the mountain area. They form the largest body of ice outside the polar caps and are the source of water for the innumerable rivers that flow across the Indo-Gangetic

*Corresponding author. E-mail: ashutoshmishrageo@gmail.com.

Author(s) agree that this article remain permanently open access under the terms of the Creative Commons Attribution License 4.0 International License 


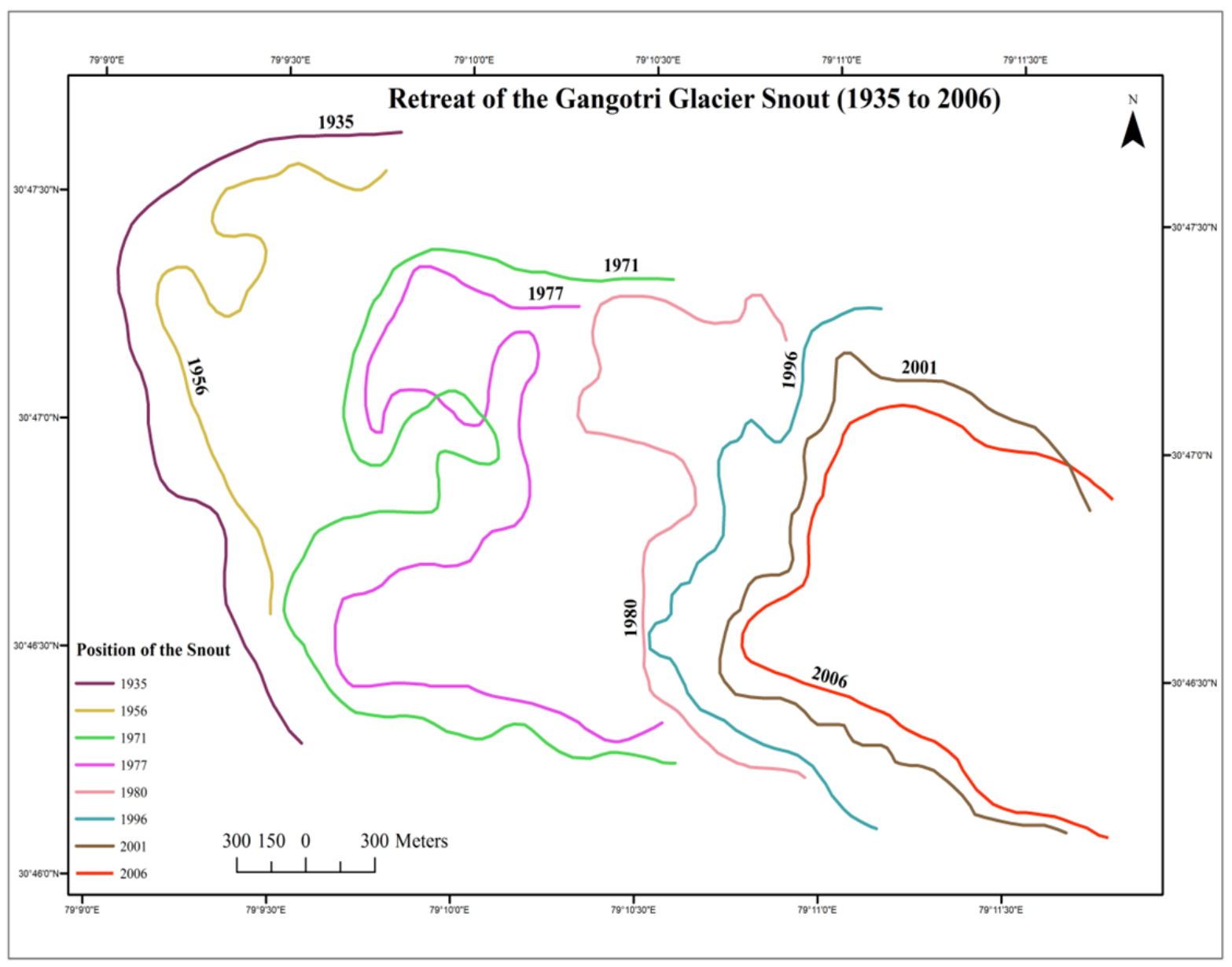

Figure 1. Retreat of the Gangotri glacier snout (1935 to 2006 based on maps made by the Geological Survey of India).

plains. About 15,000 Himalayan glaciers form a unique reservoir which supports perennial rivers such as the Indus, Ganga and Brahmaputra which, in turn, are the lifeline of millions of people in South Asian countries (Pakistan, Nepal, Bhutan, India and Bangladesh). The Gangetic basin alone is home to 500 million people, about $10 \%$ of the total human population in the region.

The Himalayan ecosystem is highly vulnerable to the stress caused by increased pressure of population, exploitation of natural resources and other related challenges. Climate change may adversely impact the Himalayan ecosystem through increased temperature, altered precipitation patterns and episodes of drought. According to IPCC's $4^{\text {th }}$ assessment report "glaciers in the Himalaya are receding faster than in any other part of the world and, if the present rate continues, the likelihood of them disappearing by the year 2035 and perhaps sooner is very high if the Earth keeps warming at the current rate. Its total area will likely shrink from the present 500,000 to $100,000 \mathrm{~km}^{2}$ by the year 2035 " (Cruz et al., 2007 cited in IPCC, 2007).

Syed Iqbal Hasnain, India's well-known Glaciologist, observes that "The Ganga system is about 60 to $70 \%$ snow and ice. There are more than 800 glaciers in the Ganga basin. The Gangotri is the big one. It used to cover more than 250 square kilometers, but now it's breaking up in many places. You will see blocks of dead ice that are no longer connected to the main ice body. I'm afraid that if the current trends continue, within 30 or 40 years most of the glaciers will melt out" (Black, 2009).

Contrary to Hasnain's view, a white paper on the status of Himalayan glaciers and global warming by V.K. Raina, former Deputy Director General of the Geological Survey of India, suggests that "in most cases glaciers have stopped retreating. While the Gangotri glacier stopped receding in the 2007-09 period, glaciers like Pindari in Kumaon continue to record a high annual retreat of almost $10 \mathrm{~m}$ annually". He further states that "The glaciers are undergoing natural changes, witnessed periodically" (Raina, 2010). According to assessments made during 1935-2006 by the Geological Survey of India, the Gangotri region has not shown any evidence of major retreat (Figure 1).

A glacier is affected by a range of physical features and a complex interplay of climatic factors. Establishing change in climate of the Himalayan region on the basis of 

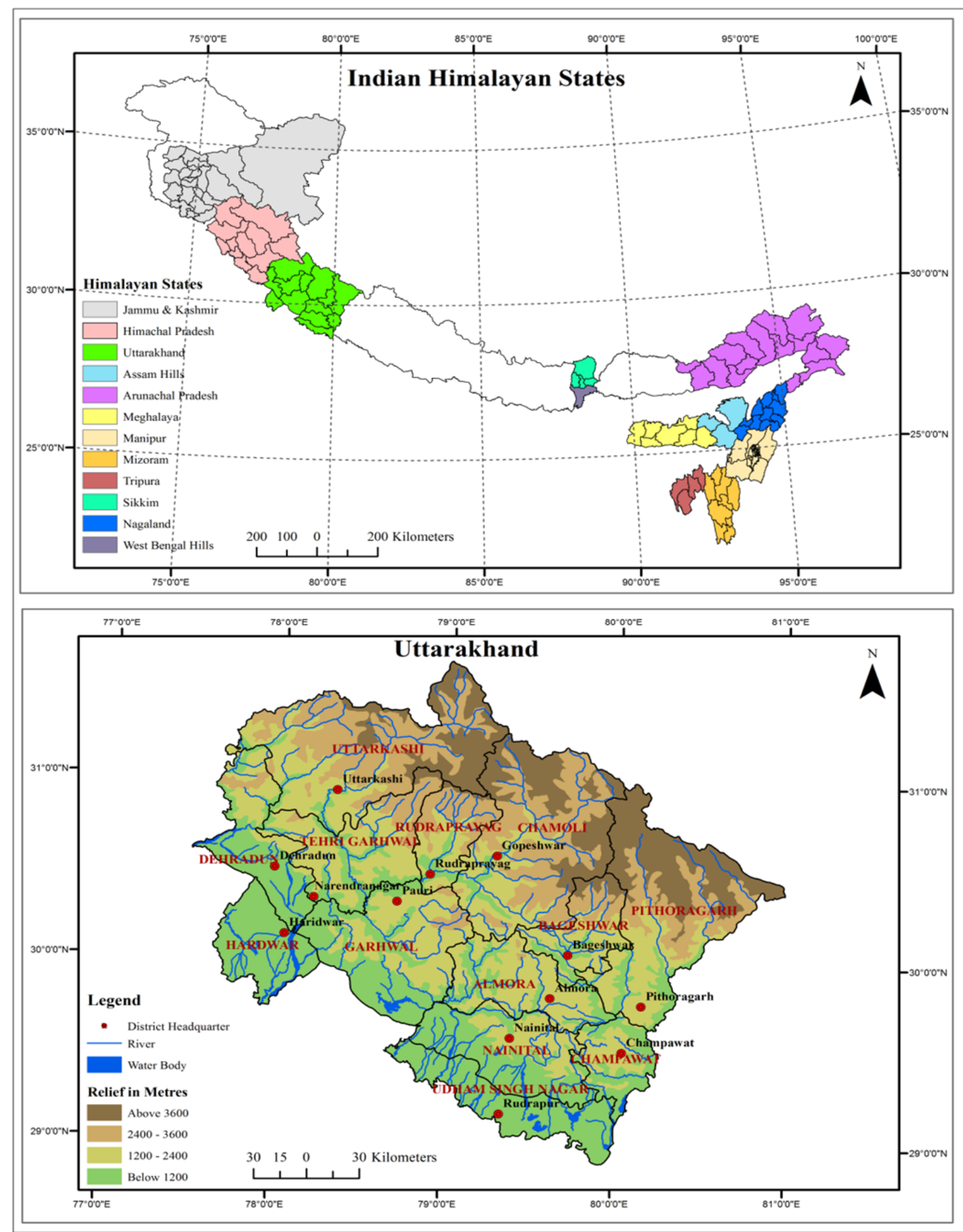

Figure 2. Location map of Uttarakhand.

movement of glaciers, and attributing this change to human activities without analysing the local climate variability, departures and level of human interference does not seems reliable.

The present work is an attempt to identify anthropogenic influence over natural climatic variability of the Himalayan region by considering Uttarakhand as the case of study. The data has been collected from Census of India, India Meteorological Department, Survey of India and Geological Survey of India, and simple correlation and regression techniques have been used for analysis of temperature and rainfall patterns.

Uttarakhand is a part of the Indian Himalayan region (Figure 2). Owing to its immense natural beauty, rich 
Table 1. Regression result for temperature and rainfall patterns.

\begin{tabular}{|c|c|c|c|c|c|c|c|}
\hline \multirow[t]{2}{*}{$S / N$} & \multirow[t]{2}{*}{ District } & \multirow{2}{*}{$\begin{array}{l}\text { Correlation between } \\
\text { temperature and } \\
\text { time series }(r)\end{array}$} & \multicolumn{2}{|c|}{$\begin{array}{l}\text { Regression result for } \\
\text { temperature series }\end{array}$} & \multirow{2}{*}{$\begin{array}{c}\text { Correlation } \\
\text { between rainfall } \\
\text { and time series }(r)\end{array}$} & \multicolumn{2}{|c|}{$\begin{array}{l}\text { Regression result for } \\
\text { rainfall series }\end{array}$} \\
\hline & & & $\mathrm{R}^{2}$ & $F$ & & $\mathbf{R}^{2}$ & $F$ \\
\hline 1 & Almora & 0.266 & 0.071 & $7.598^{\star \star}$ & -0.209 & 0.044 & $4.579^{*}$ \\
\hline 2 & Bageshwar & 0.299 & 0.089 & $9.826^{* *}$ & -0.221 & 0.049 & $5.125^{*}$ \\
\hline 3 & Chamoli & 0.315 & 0.099 & $10.984^{\star *}$ & -0.184 & 0.034 & 3.515 \\
\hline 4 & Champawat & 0.291 & 0.085 & $9.246^{* *}$ & -0.242 & 0.058 & $6.211^{*}$ \\
\hline 5 & Dehradun & 0.232 & 0.054 & $5.694^{*}$ & -0.035 & 0.001 & 0.125 \\
\hline 6 & Garhwal & 0.247 & 0.061 & $6.515^{*}$ & -0.122 & 0.015 & 1.503 \\
\hline 7 & Haridwar & 0.221 & 0.049 & $5.124^{*}$ & 0.023 & 0.001 & 0.051 \\
\hline 8 & Nainital & 0.260 & 0.068 & $7.254^{\star \star}$ & -0.201 & 0.041 & $4.229^{*}$ \\
\hline 9 & Pithoragarh & 0.342 & 0.117 & $13.250^{* *}$ & -0.236 & 0.056 & $5.919^{*}$ \\
\hline 10 & Rudraprayag & 0.308 & 0.095 & $10.514^{* *}$ & -0.153 & 0.023 & 2.404 \\
\hline 11 & Tehri Garhwal & 0.263 & 0.069 & $7.435^{\star \star}$ & -0.114 & 0.013 & 1.311 \\
\hline 12 & $\begin{array}{l}\text { Udham Singh } \\
\text { Nagar }\end{array}$ & 0.260 & 0.068 & $7.275^{\star *}$ & -0.164 & 0.027 & 2.769 \\
\hline 13 & Uttarkashi & 0.308 & 0.095 & $10.455^{\star \star}$ & -0.103 & 0.011 & 1.075 \\
\hline
\end{tabular}

**: $p<0.01,{ }^{*}: p<0.05$.

biological succession and India's great rivers feeding glaciers- Gangotri, Ponting, Milam, Pindari etc., the region is regarded as Devbhumi- abode of Gods, and Tapobhumi- land of asceticism in Indian scriptures.

The northern region of the state is part of the Great Himalayan Range, covered in snow and glaciers. Two of the Indian subcontinent's most important rivers- the Ganga and the Yamuna- also originate from the glaciers of Uttarakhand. The natural resources of the region provide life supporting, provisioning, regulating and cultural 'eco-system' services to millions of local as well as downstream people. The state lies between the longitudes $77^{\circ} 34^{\prime}-81^{\circ} 02^{\prime} \mathrm{E}$ and latitudes $28^{\circ} 43^{\prime}-31^{\circ} 27^{\prime} \mathrm{N}$ having a maximum dimension of east-west $310 \mathrm{~km}$ and north-south $255 \mathrm{~km}$. It covers an area of $53,484 \mathrm{~km}^{2}$ with the elevation ranging from 210 to $7817 \mathrm{mt}$. The state shares border with China (Tibet) in the North and Nepal in the East and inter-state boundaries with Himachal Pradesh in the West, Northwest and Uttar Pradesh in the South. Broadly, the region constitutes of 13 districts falling in two major administrative unit viz., Garhwal (northwest portion) and Kumaon (southeast portion).

The climate of Uttarakhand is temperate, marked by seasonal variations in temperature but also affected by tropical monsoons. January is the coldest month, with daily high temperatures averaging below freezing in the north and near $21^{\circ} \mathrm{C}$ in the southeast. In the north, July is the hottest month, with temperatures typically rising from 7 to about $21^{\circ} \mathrm{C}$ daily. In the southeast, May is the warmest month, with daily temperatures normally reaching the highest around $38^{\circ} \mathrm{C}$ from a low around $27^{\circ} \mathrm{C}$. Most of the state's roughly $1,500 \mathrm{~mm}$ of annual precipitation is brought by the southwest monsoon, which blows from July through September.

\section{RECENT CLIMATE TREND}

Although climate represents a set of factors and determinants showing long term averaged state of the atmosphere over a region but temperature and rainfall are the two most prominent elements among them. The present study examines trends of rainfall and temperature at annual and monthly time scales for the periods of 19112012 to understand the climatic variability of the region.

Uttarakhand has two physiographic zones- montane and non-montane. The mountainous regions have recorded more significant warming and declining rainfall trend, while Hardwar, which is almost plain, noticed positive rainfall trend (Table 1). It is evident that the temperature and rainfall departures from centennial average are significantly high in higher altitudes (Figure 3).

Data shows four distinct phases of temperature patterns during the last century- no warming or cooling up to 1950 , warming trend during 1950-1080, cooling trend between 1980-2000 and again warming after 2000. On the other hand, the rainfall patterns recorded no significant shift from natural variability at centennial scale (1911-2012) (Figure 4).

Analysis of monthly average temperature data shows very striking results. Colder months- January, February, November and December, have recorded significant warming while the hottest months- June, July, August and September, have shown cooling trend. The study area receives most of its rainfall during the months of July and August but during last century (1911-2011), these months have recorded declining precipitation trend. The months of March and May on the other hand have received more rainfall than normal (Figure 5). Interestingly, the districts of non-montane physiographic 


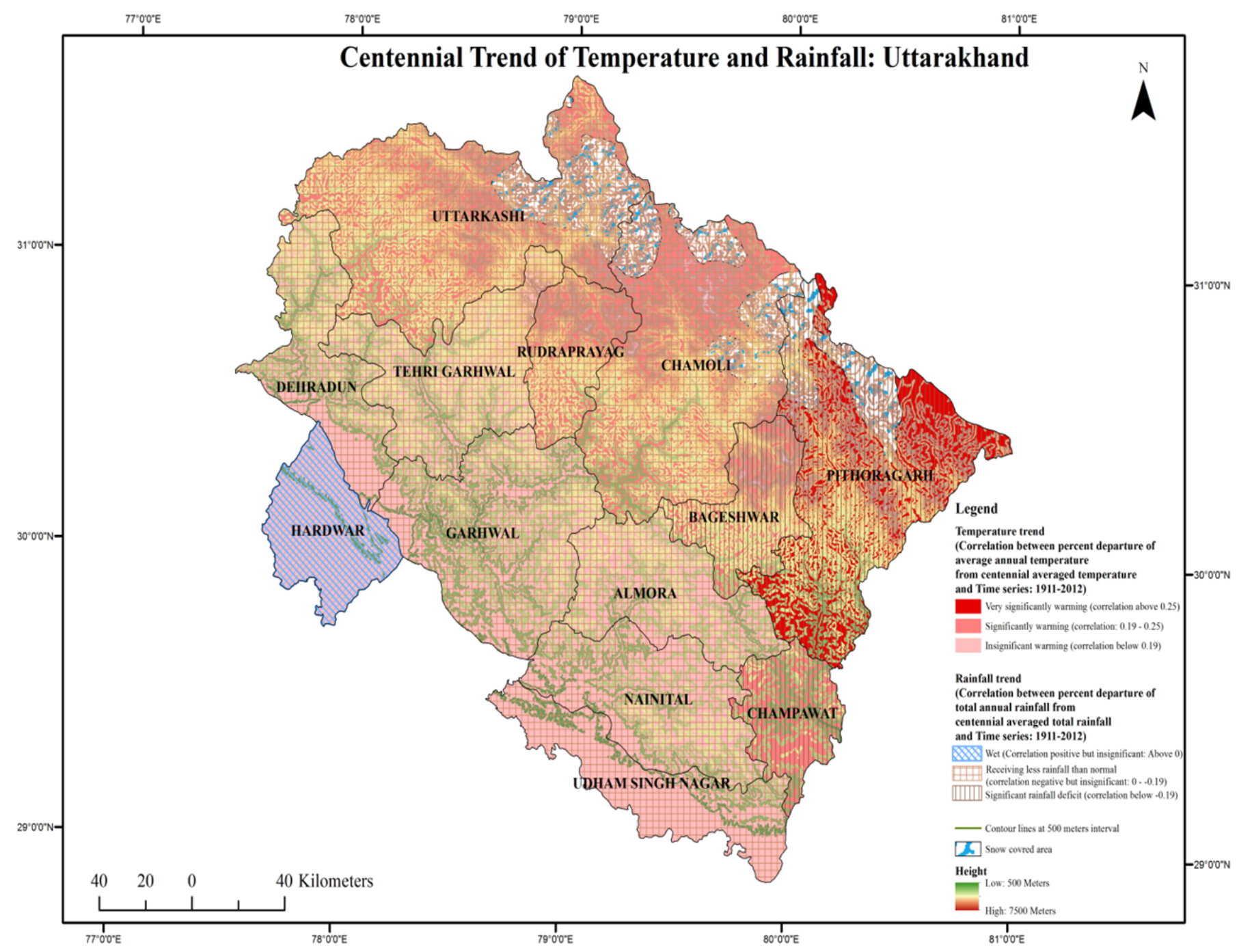

Figure 3. Temperature and rainfall trend of Uttarakhand.

zone have shown lowest departures.

The state has recorded a continuous growth in population during the last century except in 1921-31, however the urban population has grown at faster rate. Most of the population lives in the lower districts where urban share is high (Figure 6).

Hardwar and Dehradun districts record the highest population and percent urbanisation, and have the highest number of census towns (Table 2). These two districts have noticed less warming than others. Contrary to other districts, Hardwar has recorded an increasing rainfall trend although this trend is insignificant. Evidently urbanisation holds no significant association with temperature and rainfall trends.

Heavy forest diversion for basic infrastructures is also being accused for deteriorating local climate's stability. But data suggests that green cover removal is not directly related with the warming. Dehradun and Hardwar which have recorded largest forest diversion are not the warmest districts of the region (Table 3). Forests attract rainfall, but here Hardwar having the noticeable forest diversion, has shown an increasing rainfall trend.

Uttarakhand is famous for religious and adventure tourism. Noticeably the tourist pressure at four major religious centres of the state has been almost doubled during the last twelve years (Table 4).

The three districts - Uttarkashi, Rudraprayag and Chamoli, where these religious centres are located, have recorded very significant warming during past decade. Increasing vehicular pollution seems fuelling temperature rise in these areas. Although growing industrialisation and vehicular density in Dehradun and Hardwar districts have no significant impression on temperature trend on the other hand, it can be said that vehicular pollution is more significantly correlated with temperature patterns in hilly areas while in the plain region, it has less impact on 

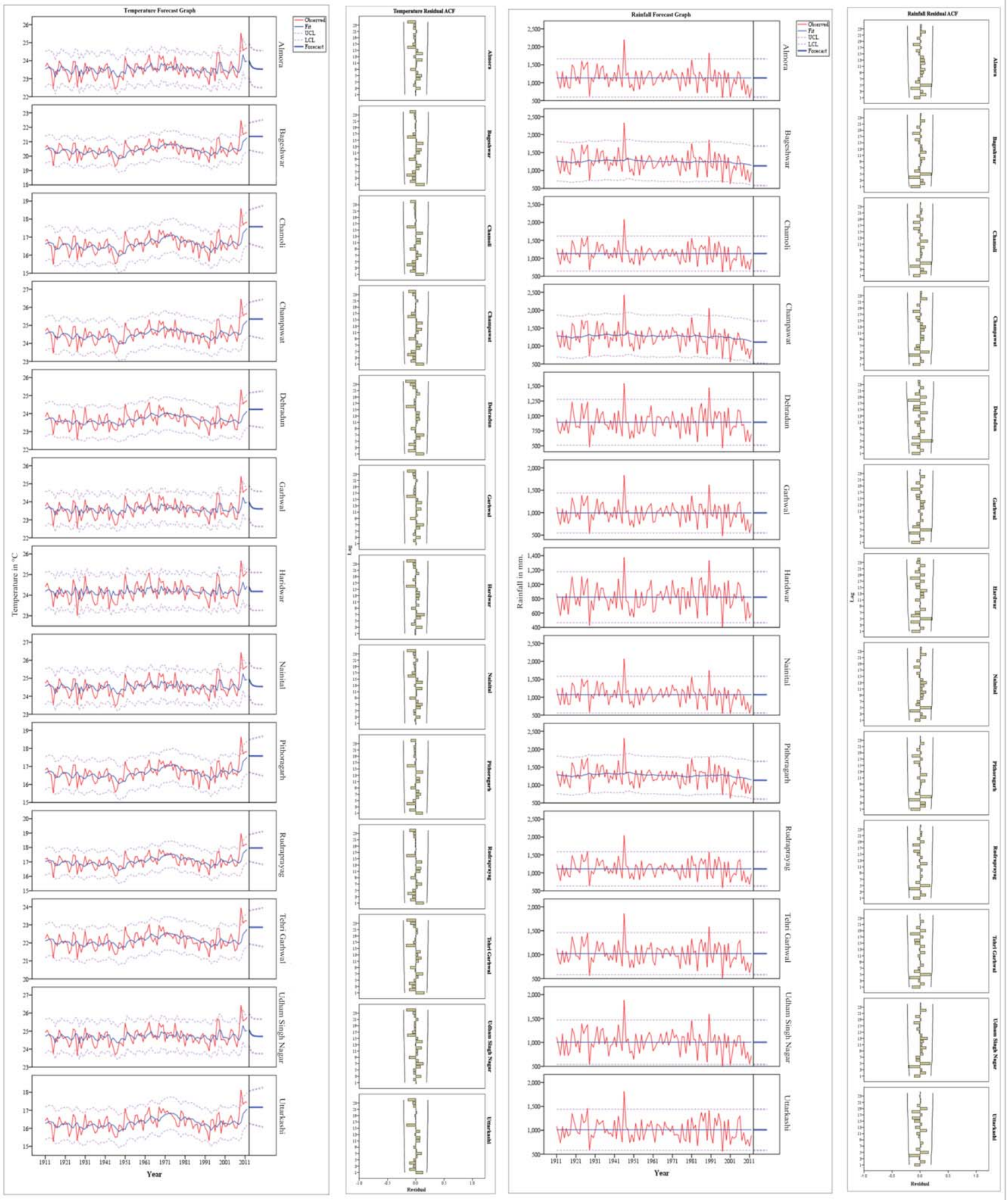

Figure 4. District level temperature and rainfall forecast graph for Uttarakhand. 


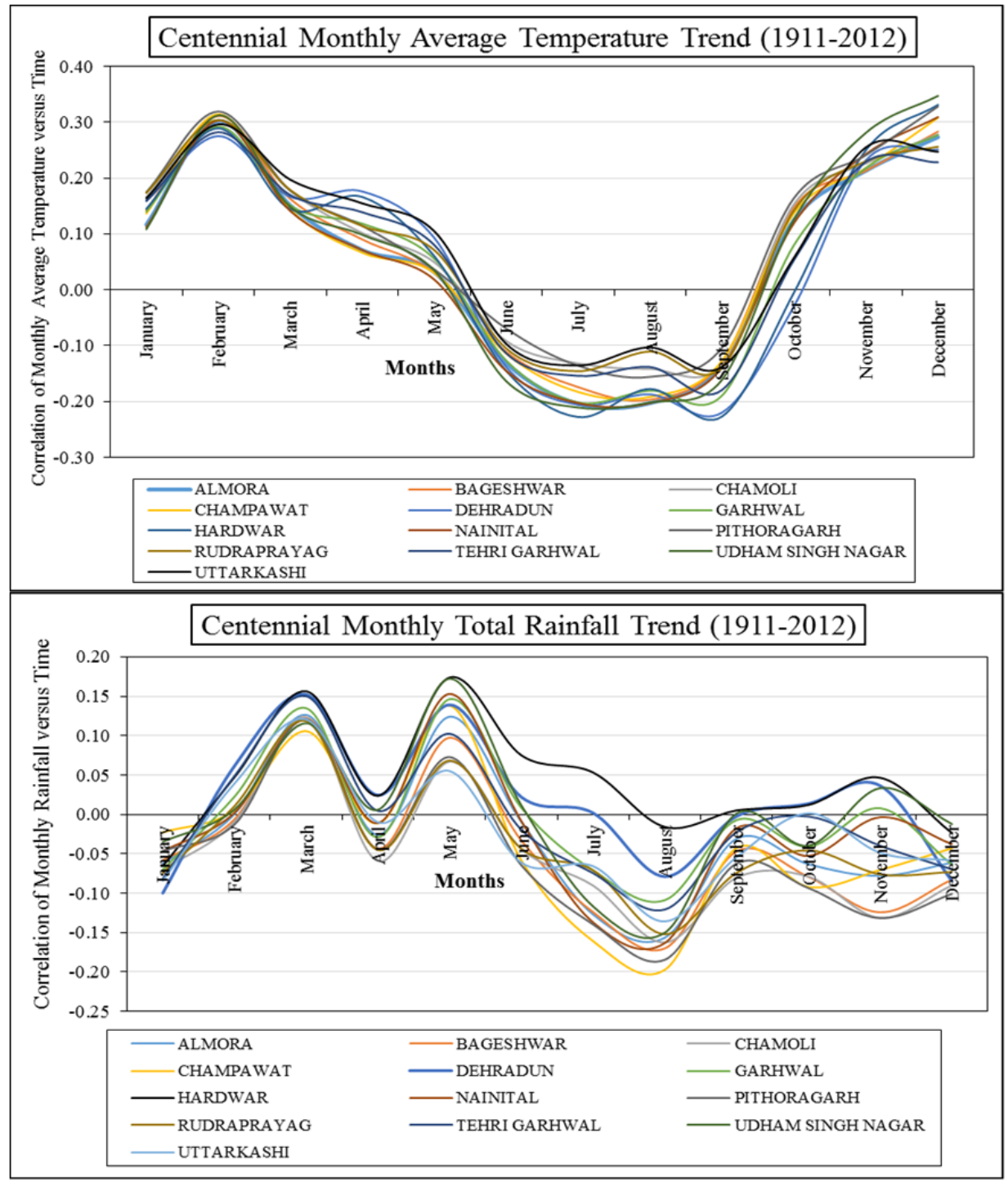

Figure 5. District level centennial monthly temperature and rainfall trend of Uttarakhand (correlation values above 0.19 are significant and above 0.25 are highly significant).

the atmospheric state. In other words, neutralising capacity of plain ecosystem seems greater than mountainous ecosystem.

\section{CONCLUSION}

Analysis shows noticeable departures in temperature and rainfall patterns. Months of March and May have recorded more rainfall and significant warming. Temperature of June, July, August and September are at cooler side. Result shows that surface temperatures have risen significantly during the last century, but this may be result of various cooling and warming phases. Besides having significant temperature-time correlations, $R^{2}$ values are very weak because of very noisy data. The ARIMA models predicted warming up to $0.3^{\circ} \mathrm{C}$ till 2035 , being maximum for Chamoli district. Results show that this change is almost natural rather than anthropogenic. Warming is unequivocal with decreasing rainfall (except Hardwar), however, temperature and rainfall patterns do not fully support the hypothesis that urbanisation, industrialisation or green cover removal have great bearing on this warming or drying trend. Although increasing vehicular pollution in temperature-sensitive high altitude areas seems to have some impact on these trends, we can say while human interference has fuelled some variations in patterns, natural factors are the major cause behind climatic variability and changes. IPCC's claim that due to human intervention in the Himalayan ecosystem, by 2035 we are going to lose large volume of glaciers, thus, does not seem a real claim. 


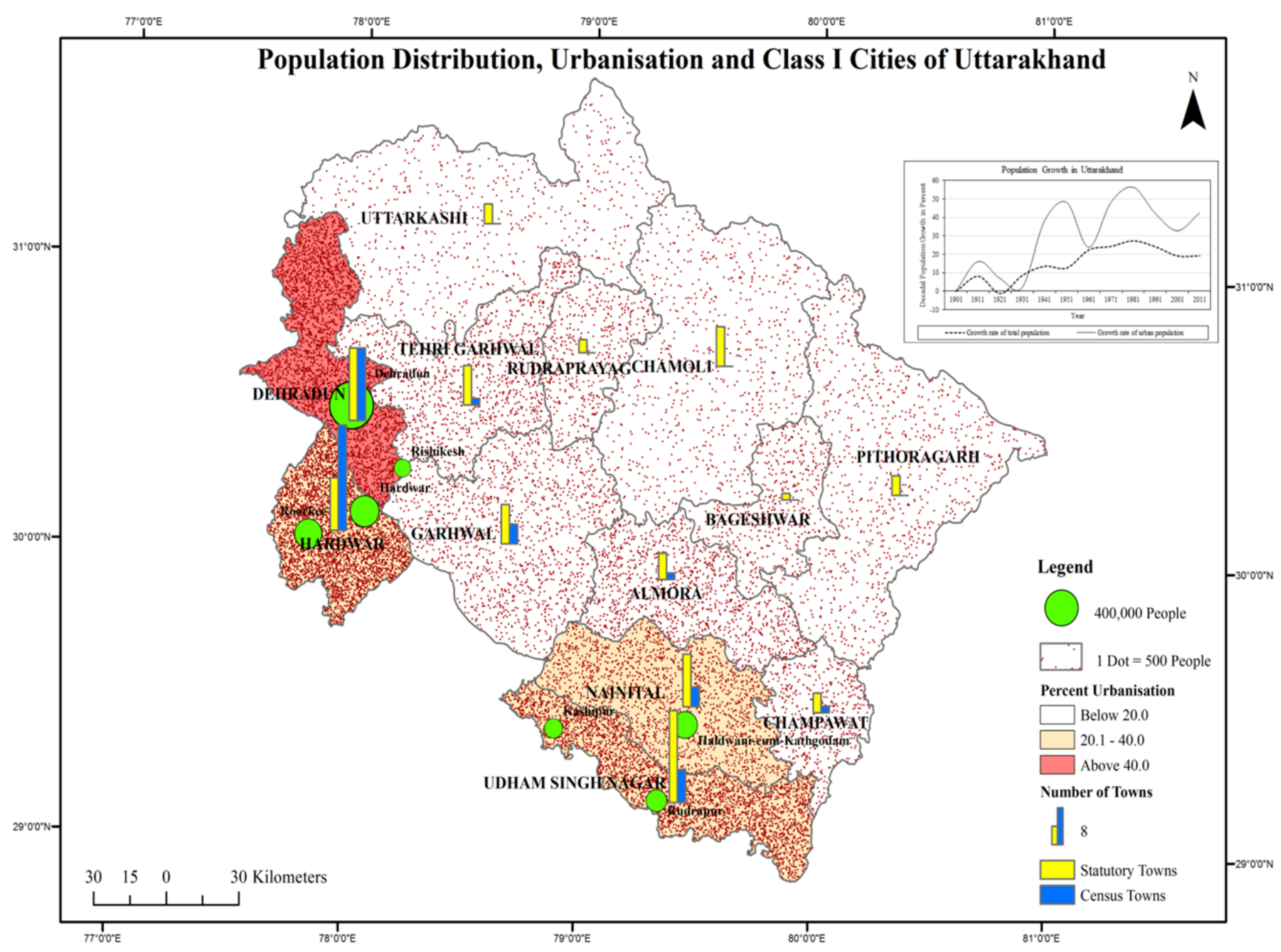

Figure 6. Population distribution in Uttarakhand.

Table 2. Urbanisation in Uttarakhand.

\begin{tabular}{|c|c|c|c|c|c|c|}
\hline S/N & District & Total population & Percent urbanisation & Statutory towns & Census towns & Village \\
\hline 1 & Almora & 621927 & 10.02 & 4 & 1 & 2289 \\
\hline 2 & Bageshwar & 259840 & 3.5 & 1 & 0 & 947 \\
\hline 3 & Chamoli & 391114 & 15.11 & 6 & 0 & 1246 \\
\hline 4 & Champawat & 259315 & 14.79 & 3 & 1 & 717 \\
\hline 5 & Dehradun & 1698560 & 55.9 & 11 & 11 & 748 \\
\hline 6 & Garhwal & 686527 & 16.41 & 6 & 3 & 3473 \\
\hline 7 & Hardwar & 1927029 & 37.77 & 8 & 16 & 612 \\
\hline 8 & Nainital & 955128 & 38.94 & 8 & 3 & 1141 \\
\hline 9 & Pithoragarh & 485993 & 14.31 & 3 & 0 & 1675 \\
\hline 10 & Rudraprayag & 236857 & 4.19 & 2 & 0 & 688 \\
\hline 11 & Tehri Garhwal & 616409 & 11.37 & 6 & 1 & 1862 \\
\hline 12 & Udham Singh Nagar & 1648367 & 35.58 & 14 & 5 & 688 \\
\hline 13 & Uttarkashi & 329686 & 7.35 & 3 & 0 & 707 \\
\hline
\end{tabular}

Source: Census, 2011, GOI and computed. 
Table 3. District wise/sector wise details of forest area diverted from 2000 to 2013.

\begin{tabular}{|c|c|c|c|c|c|c|c|c|}
\hline \multirow[b]{2}{*}{ District } & \multirow{2}{*}{$\begin{array}{c}\text { Total forest } \\
\text { diverted area in } \\
\text { hectare }\end{array}$} & \multicolumn{7}{|c|}{ Percent of the total forest diverted area for different purposes } \\
\hline & & $\begin{array}{c}\text { Road } \\
\text { construction }\end{array}$ & $\begin{array}{c}\text { Managing } \\
\text { drinking water }\end{array}$ & Irrigation & $\begin{array}{c}\text { Electricity } \\
\text { transmission lines }\end{array}$ & $\begin{array}{l}\text { Hydroelectric } \\
\text { power plants }\end{array}$ & Mining & Other uses \\
\hline Almora & 816.29 & 88.36 & 1.7 & 0.61 & 2.94 & 0.01 & 0 & 6.39 \\
\hline Bageshwar & 559.05 & 67.73 & 1.57 & 0.52 & 0.99 & 2.88 & 20.01 & 6.3 \\
\hline Chamoli & 2097.74 & 44.85 & 0.46 & 0.05 & 37.45 & 11.54 & 0.05 & 5.59 \\
\hline Champawat & 738.57 & 37.76 & 0.8 & 0.28 & 0.49 & 0 & 52.09 & 8.58 \\
\hline Dehradun & 19496.09 & 2.05 & 0.05 & 0.01 & 0.13 & 0 & 8.22 & 89.54 \\
\hline Garhwal & 677.4 & 43.97 & 2.95 & 0.18 & 24.69 & 0.43 & 21.48 & 6.3 \\
\hline Haridwar & 5197.71 & 1.16 & 0 & 0.31 & 0.16 & 0 & 55.79 & 42.57 \\
\hline Nainital & 3165.71 & 13.71 & 2.24 & 0.32 & 0.61 & 0 & 77.14 & 5.98 \\
\hline Pithoragarh & 1667.66 & 66.42 & 0.58 & 0.1 & 29.6 & 0.75 & 0.25 & 2.3 \\
\hline Rudraprayag & 389.56 & 66.19 & 1.76 & 2.36 & 3.99 & 16.16 & 0 & 9.55 \\
\hline Tehri Garhwal & 1591.74 & 30.35 & 1.16 & 0.08 & 9.88 & 44.46 & 0.41 & 13.67 \\
\hline Udham Singh Nagar & 156.23 & 9.15 & 0 & 2.3 & 3.16 & 0 & 0 & 85.39 \\
\hline Uttarkashi & 830.95 & 52.71 & 1.1 & 0.95 & 13.22 & 27.59 & 0 & 4.44 \\
\hline
\end{tabular}

Source: Uttarakhand forest statistics, Forest Department, Government of Uttarakhand, p. 44.

Table 4. Tourist inflow at selected location in Uttarakhand.

\begin{tabular}{llc}
\hline Place & District & Percent increase in tourist Inflow (2001-2012) \\
\hline Yamunotri & Uttarkashi & 240 \\
Gangotri & Uttarkashi & 250 \\
Kedarnath & Rudraprayag & 378 \\
Badrinath & Chamoli & 136 \\
\hline
\end{tabular}

Source: CSE, 2013.

\section{Conflict of interests}

The authors did not declare any conflict of interest.

\section{REFERENCES}

Black G (2009). India Enlightened. On earth, summer edition, pp. 28-29.
Cruz RV Harasawa $\mathrm{H}$, Lal M, Wu S, Anokhin $Y$, Punsalmaa, B, Honda $Y$, Jafari M, Li C, Huu NN (2007). Asia. In ML Parry, OF Canziani, JP Palutikof, PJ Linden, Hanson CE (eds.), Climate Change 2007: Impacts, Adaptation and Vulnerability, Contribution of Working Group II to the Fourth Assessment Report of the Intergovernmental Panel on Climate Change, Cambridge University Press, Cambridge, UK, pp. 469-506.

NDMA (2007). National Disaster Management Guideline National Disaster Management Authority, Government of India, p. 1
Raina VK (2010). Himalayan Glaciers: A State-of-Art Review of Glacial Studies, Glacial Retreat and Climate Change. MOEF Discussion Paper, Ministry of Environment and Forests, Government of India, p. 7. 